\title{
JOHN A. KASSON'S OPPOSITION TO THE LINCOLN ADMINISTRATION'S MEXICAN POLICY
}

\author{
by Thomas Schoonover \\ Lafayette, Louisiana
}

Professor Schoonover is an Assistant Professor of History at the University of Southwestern Louisiana. He was born, raised and educated in Minnesota and received his Ph. D. in United States Foreign Relations at the University of Minnesota. Professor Schoonover also holds an M. A. in Civil War History.

On 4 April 1864 the United States House of Representatives unanimously passed a joint resolution condemning the French efforts to establish the Archduke Maximilian as Emperor of Mexico. The resolution stated:

Resolved: That the Congress of the United States are unwilling by silence to have the nations of the world under the impression that they are indifferent spectators of the deplorable events now transpiring in the Republic of Mexico, and that they think fit to declare that it does not accord with the policy of the United States to acknowledge any monarchical government erected on the ruins of any re publican government in America under the auspices of any European power. $^{1}$

Passing with almost no debate, this resolution has been named the Davis resolution after the man who reported it out of Committee, Henry Winter Davis, chairman of the House Committee on Foregin Relations. ${ }^{2}$ It is the purpose of this paper to demonstrate that John A. Kasson, Congressman from Iowa, was the initiator of this resolution. While the evidence of his major role in conceiving this antiFrench resolution is clear, it is equally clear that no satisfactory explanation of his motives can be offered.

The resolution had several immediate effects. First, the French government was annoyed and angered, feeling this resolution was intended as an open challenge to her honor. ${ }^{3}$ Second, the Mexican government interpreted the resolution to indicate the growing swell of opinion in the United States favoring aid to President Benito Juarez beleaguered Liberal government. Third, the resolution was an obvious effort on 
the part of Radical leaders to embarrass the Lincoln-Seward administration's conduct of foreign policy. The Radicals hoped to weaken the political position of Lincoln and strengthen that of the Radical's fair-haired boy, John C. Fremont, an open candidate for the Republican presidential nomination in $1864 .{ }^{4}$ It is in conjunction with this latter point that Kasson's action is difficult to explain.

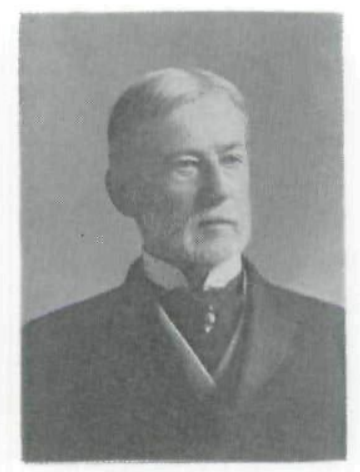

John A. Kasson

Kasson was supposedly a strong administration supporter. Yet, Lincoln and Seward had followed a consistent policy with regard to the French intervention in Mexico since it began in Dec. 1861. They recognized the sovereign right of France to determine its own course of action, including war, if it felt its rights had been violated and Mexico offered no acceptable alternative solution. Lincoln and Seward did not recognize France's right to alter the Mexican form of government, or to intervene in Mexico's internal affairs. However, Lincoln and Seward were determined, while the Civil War continued, to do no more than state their position, without attempting to enforce their policy. ${ }^{5}$ It is difficult to comprehend that Kasson, who had served the Lincoln administration as Assistant Postmaster General and as a delegate to the International Postal Convention in Paris in 1863, and, who was a friend of both Lincoln and Postmaster General Montgomery Blair, could have prepared the original draft of a resolution so critical of United States foreign policy. His long connection with the Lincoln administration and his friendship with key figures in the government led Edward Younger, Kasson's biographer, to describe him in the winter of 1863-1864 and the spring of 1864 as "an administration leader," and "a strong administration man." Furthermore, Younger stated: "Kasson's hand in the renomination of Lincoln [in 1864] although by no means crystal clear, is more discernible than that of his reticent Iowa congressional colleagues." Younger's description hardly fits 
the author of a most pointed political act intended to weaken the administration.

Of course, traditionally, no explanation has been necessary since Kasson has not been associated with this resolution. Historians have labelled the resolution the Davis resolution, and nobody questioned the desire of Henry Winter Davis, a House radical leader, to embarrass the Lincoln administration. But, how did the resolution originate? What people were responsible for seeing it through to unanimous adoption in the House? Three people had key roles, Henry Winter Davis, John A. Kasson, and Matias Romero, Mexican Minister to the United States. Since Romero served as coordinator and information center for almost all actions in the United States sympathetic to Mexico, and since it is largely through his papers and dispatches that the origin and the course of the resolution can be followed, his return to the United States in the late fall of 1863 as Minister to the United States can serve as a starting point for understanding Kasson's and Davis' involvement in United States policy toward Mexico.

Romero had served as charge d'affaires for Mexico from before the outbreak of the Civil War until the spring of 1863. He resigned then, only because the Juarez government could not afford to give him sufficient funds to lobby in the politically influencial circles of Washington. He returned in the fall of 1863 as Mexican Minister after assurances were given him that he would receive an adequate salary and an expense allowance sufficient to permit effective lobbying on his part. He had long been convinced he was not going to achieve meaningful aid to Mexico through Seward and the normal diplomatic channels. Immediately upon his return he began to look for a house in which he could entertain the influential of Washington at formal dinners. Just before Christmas he rented a house, spent the next month furnishing it, acquiring and training a staff, and giving trial dinners to work out any problems that might exist. ${ }^{8}$

Then, on the evening of Jan. 21, 1864, Romero began earnestly to eat his way into Washington's inner political and diplomatic circles. In less than sixty days he gave sixteen 
formal dinner parties, thirteen of them aimed primarily at the Cabinet, the Senate and the House. Every member and most of the Senate and House leaders - some fifty congressmen in all, including Charles Sumner, John Sherman, Lyman Trumbull, Benjamin Wade, Schuyler Colfax, Thaddeus Stevens, Zachariah Chandler, Reverdy Johnson, John A. Kasson, and Henry Winter Davis were guests at his table. Vice President Hannibal Hamlin was entertained as were Supreme Court Justices Samuel F. Miller and Stephen J. Field. The dining continued after the initial sixty-day period without any noticeable slackening, the only change being that Romero began to repeat invitations to certain guests, something he had rarely done during the first two months. ${ }^{9}$

Even before launching his intensive, and certainly expensive lobbying campaign, Romero collected dividends. On the evening of Jan. 18, 1864, Kasson called on Romero with some resolutions on Mexican affairs which were hostile toward France that he wished to present in the House. Kasson assured Romero they would pass unanimously. Romero believed they most certainly would pass, but to assure their success, Romero decided to press for their passage and to let up on a set of alternate resolutions McDougall had introduced in the Senate. Romero had learned that Sumner's opposition in the Senate was impossible to combat successfully. Sumner often agreed in principle with Romero, yet disagreed over the method or manner of objecting to French intervention in Mexico. Sumner feared any strange action might produce an undesired reaction on the part of the French - undesired by the United States at least while the Civil War continued. ${ }^{10}$

After consulting with Romero again on Jan. 25th and 27th, Kasson read his revised resolutions on the 28th. Two days later, Henry Winter Davis, Chairman of the House Committee on Foreign Affairs, visited Romero to discuss Mexican affairs. Again Romero discovered a friend of Mexico. Davis had not then read Kasson's resolution, but he intended to in the immediate future. More significant was Davis' statement that he had prepared resolutions on the same matter and if Kasson's were similar in tone, he would see that Kasson's 
were treated as eminating from the Foreign Affairs Committee. ${ }^{11}$

The matter rested for several weeks, then in late Feb., 1864, Romero met with Kasson and Davis to inquire about the resolutions' progress. The two Congressmen believed the French government was tired of the intervention and wanted to leave Mexico. Romero cited the debates of the Corps Legislatif as reported in the Moniteur, Napoleon's official newspaper, to convince Davis that more pressure was needed. On March 2, 1864, the House passed a resolution asking the executive for the correspondence on Mexico, a first step toward building up pressure for a strong congressional course of action. ${ }^{12}$

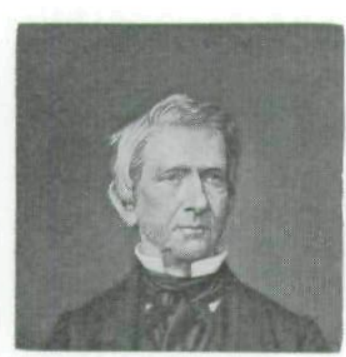

W. H. Seward Secretary of State

In mid-March Romero pushed for action. He had just learned that, earlier, Seward had called the members of the House Foreign Affairs Committee into his office and pressured them not to act upon the Kasson or Davis resolutions. Nothing quite so stirred Romero to action between 1862 and 1865 as the chance to do battle with Seward. On March 16th, Davis and Romero had a long conversation during which Romero's passionate, glowing presentation solicited from Davis an offer to take action at the next Foreign Affairs Committee meeting. Romero's argument was that the resolutions would make the French expedition unpopular in France, would cause Maximilian to vacillate in accepting the crown, and would animate the Mexican people to greater resistance. Romero claimed this was possible at no risk of the danger Seward and Davis claimed to fear of a strong French reaction. There was no danger, as Romero carefully explained, since, as the Seward-Sumner alliance controlled the Senate on matters relating to the United States' Mexican policy, this joint resolution would never take effect. On March 23rd, Davis informed Romero his committee had been approved recommendation of a substitute for Kasson's resolutions which incorporated their intent into one stinging resolution. ${ }^{13}$ 
Thus, on April 4th Romero's new political campaign for Mexico won its first major victory with the introduction of a resolution against French intervention in Mexico, and of course, indirectly against the Seward-Lincoln conduct of foreign relations. This resolution, the Kasson-Davis resolution, but known, nevertheless, as the Davis resolution, passed 109-0. As strong as Davis' resolution was, Romero was unhappy with it. He was sure that Seward had somehow persuaded Davis to soften the resolution. ${ }^{14}$

Romero also influenced Congressional criticism of Seward's policy in May, 1864. On the 19th, Romero showed Davis the explanations Seward gave the French government relative to Davis' April 4th resolution as published in the Moniteur. Seward claimed the executive was sole formulator of foreign policy and further pointed out that, since the Davis resolution was a joint resolution which the Senate had not approved, it was not even a valid congressional statement of policy. Davis' efforts to get political mileage out of this were to be delayed until the winter of 1864-1865 due to the recess of Congress at the beginning of July. While their reasons for wishing the Seward-Lincoln administration to fall varied, Romero and Davis used Seward's domestic political blunder of belittling Congress' foreign policy role for their ends. Davis, professing his belief that Congress was the chief source of popularly expressed will, thought that Seward and Lincoln were obstructing the implementation of the national will regarding French involvement in Mexico. Behind Davis' theory of the source of sovereignty was his and his fellow Radicals' practical problem: they wanted to exercise more power and greater control over wartime and postwar reconstruction policy. ${ }^{15}$ Romero, on the other hand, in thinking Seward was following a policy friendly to France and unfriendly to Mexico, believed that as long as Lincoln remained President, Seward would continue as architect of foreign policy.

The roles of the three, Kasson, Davis, and Romero are thus easy to describe. Kasson was the author of the resolution, although it may have been slightly modified in Davis' Foreign Relations Committee. Davis was the energy, the power and 
the influence pushing the resolution through his committee and onto the floor of the House. Moreover, since Davis had a similar idea at that time, he was practically co-author. Romero was the behind-the-scenes coordinator who kept Davis informed and angry toward Seward. Thus, while the Mexican archival material permits us to understand the roles of the three individuals, and even the motivation of Davis and Romero, one great mystery remains: Why did Kasson introduce and support such a resolution? Perhaps Kasson's status as "a strong administration man" will have to be re-examined. Perhaps, also, it was merely an error, a blunder on his part. Until more evidence is produced we can only ponder the motives Kasson may have had for his seemingly illogical action during the period from Jan. until April, 1864.

\section{Notes}

${ }^{1}$ Dexter Perkins, The Monroe Doctrine, 1826-1867 (Baltimore: The Johns Hopkins Press, 1933), 451 mistakenly dated these actions 6 April. See Cong. Globe, 38th Cong., 1st Session, 1408 (4 April 1864) for the resolution and its passage.

${ }^{2}$ Only Perkins, The Monroe Doctrine, 449-452, even mentioned Kasson's name in connection with the resolution, but he also labeled it Davis' resolution in the index, p. 565, and in the text, p. 452. All other historians either refer to it as Davis' resolution or the resolution introduced by Davis.

${ }^{3}$ After receiving a report of the House Resolution the French Foreign Minister Edouard Drouyn de Lhuys greeted United States Minister William L. Dayton with "Do you bring us peace or bring us war?" Glyndon G. Van Deusen, William Henry Seward (New York: Oxford University Press, 1967), 368.

${ }^{4}$ Matías Romero to the Ministro de Relaciones Exteriores, Washington, 27 December 1862, in Matías Romero (comp). Correspondencia de la legación mexicana en Washington durante la intsrvención extranjera (10 vols.; Mexico: Imprenta del Gobierno, 1870-1892), II, 743-746; Romero to the Ministro de Relaciones Exteriores, Washington, 19 January 1863, in Romero, Correspondencia, III, 124-125; Romero to the Ministro de Relaciones Exteriores, Washington, 21 January 1861, in Romero, Correspondencia, IV, 10; Matías Romero, Diario Personal, edited by Emma Cosío Villegas (Mexico: El Colegio de Mexico, 1960), $585-615$ for the frequency of his contact with anti-administration politicians.

${ }^{5}$ Thomas D. Schoonover, "Mexican-United States Relations, 18611867," (Ph.D. dissertation, University of Minnesota, 1970), 139-141; Henry Blumenthal, A Reappraisal of Franco-American Relations, 18301871 (Chapel Hill: The University of North Carolina Press, 1959), 169; Van Deusen, William Henry Seward, 366-371.

${ }^{6}$ Edward Younger, John A. Kasson: Politics and Diplomacy from Lincoln to McKinley (Iowa City: State Historical Society of Iowa, 
$1955)$, 160-161, for the specific references. Chapter $X, 153-176$, is entitled: "A Lincoln Moderate in Congress."

${ }^{7}$ Younger, John A. Kasson, 165.

${ }^{8}$ Romero, Diario, pp. 557-576; Romero to the Ministro de Relaciones Exteriores, Washington, 26 February 1863, in the Archivo de la Secretaria de Relaciones Exteriores (Mexico), bound volume H/110 (73-0) “863"/1., 12-C-R-1, pp. 57-59 (hereafter cited as Romero to MRE, Wash., 26 Feb. 1863, ASRE, H/110(73-0) “863"/1., 12-C-R-1, pp. 57-59). Also found in the Archivo Matías Romero, Banco de Mexico, Mexico City, folio 00220.

${ }^{9}$ Romero, Diario, pp. 576-588.

${ }^{10}$ Romero, Diario, 576; Romero to MRE, Wash., 19 Jan. 1864, ASRE, H/110 (73-0)“863”/1., 12-C-R-1, p. 244; Younger, John A. Kasson, contains no mention at all of any relationship between Kasson and Romero, or Mexico, or the French intervention. See Chapters 7, $8,9,10$, and 11 on the Lincoln and Johnson administrations and the index under "Romero," "Mexico," "French intervention," "Napoleon," "Monroe Doctrine," and "Seward."

${ }^{11}$ Romero, Diario, pp. 577-579; Romero to MRE, Wash., 30 Jan. 1864, and 31 Jan. 1864, ASRE, H/110(73-0) “863"/1., 12-C-R-1, pp. $259,261-262$.

${ }^{12}$ Romero, Diario, 585, Romero to MRE, Wash., 2 Mar. 1864 enclosing Romero to Henry Winter Davis, Wash., 27 Feb. 1864, and Davis to Romero, [Wash.] 1 Mar. 1864 (mistakenly dated 1 May 1864), ASRE, H/110(73-0)“863"/1., 12-C-R-1, pp. 384-389.

${ }^{13}$ Romero, Diario, 589; Romero to MRE, Wash., 16 Mar. 1864, and 23 Mar. 1864, ASRE, H/110(73-0)“863"/1., 12-C-R-1, pp. 436-437, 447-448. In 1861-1862 Romero and Sumner had amiable relations. After the Senate Foreign Relations Committee's recommendation to accept the Corwin loan treaty in principal was rejected, Sumner altered his attitude. Thereafter he felt the Civil War had first priority. Mexico would have to wait until the domestic problem was solved. Naturally, Romero did not agree with this attitude. Beginning in 1862 Seward and Sumner usually agreed on broad foreign policy issues in relation to Mexico and foreign intervention in that country. See Van Deusen, William Henry Seward, 316, 367; Romero to MRE, Wash., 23 June 1864, in Romero, Correspondencia, IV, 237-238.

${ }^{14}$ Romero to MRE, Wash., 6 Apr. 1864, in Romero, Correspondencia, IV, 122-123; in fact the vote reached more than 109-0 since on the following day, 5 April, two more Congressmen, Justin S. Morrill (Rep., Vermont) and George H. Pendleton (Dem., Ohio), obtained permission to register their voted in the affirmative, a privilege extended to all who were absent on 4 April. Cong. Globe, 38th Cong., 1st session (1863-1864), 1408 (4 April 1864), 1426-1427 (5 April 1864).

${ }^{15}$ Romero, Diario, 600; Marvin Goldwert, "Matías Romero and Congressional Opposition to Seward's Policy Toward the French Intervention in Mexico," The Americas, XXII (July, 1965), 30-33. Davis' congressional efforts to chastise the administration in the winter of 1864-1865 fall outside the scope of this paper, involving contest for control of foreign affairs between the executive and Congress, Bernard C. Steiner, Henry W. Davis (Baltimore: John Murphy Company, 1916), 316-319; Eric L. McKitrick, Andrew Johnson and Reconstruction (Chi- 


\title{
Reminiscences
}

cago: The University of Chicago Press, 1960), 93-119, and T. Harry Williams, Lincoln and the Radicals (Madison: The University of Wisconsin Press, 1960), 324-325 describe various Radical theories of Congress' role in the United States government.

\section{REMINISCENCES OF A PIONEER BOY}

\author{
PART II \\ by Ellison Orr
}

\section{Edited with an Introduction \\ by Marshall McKusick \\ State Archaeologist \\ lowa City, lowa}

Part I of the "Reminiscences" appeared in the Winter issue of the ANNALS, No. 7, 1971.

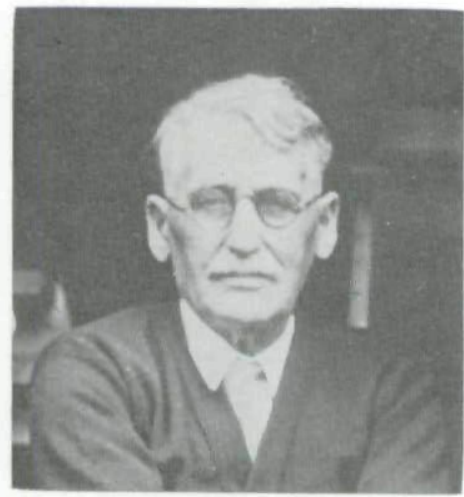

Ellison Orr

The author of Reminiscences of a Pioneer Boy was born in a $\log$ cabin on his father's farm in 1857 and grew up in the rugged hill country of northeast Iowa in Allamakee County. As a young man he taught school, was a bank clerk, and later worked as surveyor, land salesman and finally became clerk of court in Waukon, the countyseat. In 1904 Orr became a businessman, managing the telephone company for the next twenty-five years. A well known amateur naturalist, Ellison Orr joined Dr. Charles R. Keyes of the Iowa Archaeological Survey in 1934 and during the 1930s directed the major excavations of the Survey throughout the State. Although Orr was 77 years old when he joined the Survey and retired finally at the age of 83 , he made a lasting contribution to scholarly research. His explorations were the first well-controlled and representative excavations made in Iowa, and his manuscript archaeological reports have been frequently cited by professional archaeol- 
Copyright of Annals of Iowa is the property of State of Iowa, by \& through the State Historical Society of Iowa and its content may not be copied or emailed to multiple sites or posted to a listserv without the copyright holder's express written permission. However, users may print, download, or email articles for individual use. 